SAKAI SAMBAYAN — Jurnal Pengabdian kepada Masyarakat

\title{
PEMBUATAN ALAT PENJERNIH AIR MENGGUNAKAN ARANG SEKAM PADI DI KAMPUNG YUDHA KARYA JITU KECAMATAN RAWA JITU SELATAN KABUPATEN TULANG BAWANG PROPINSI LAMPUNG
}

\author{
Asroni*, Arif Hidayat \\ Jurusan Teknik Mesin Universitas Muhammadiyah Metro \\ Jl. KH Dewantara No.116 Iringmulyo, Metro Timur, Kota Metro 34111 \\ Penulis Korespodensi : asroni14@yahoo.com
}

\begin{abstract}
Abstrak
Bagi warga desa Yudha Karya Jitu, air bersih merupakan kebutuhan yang tak ternilai harganya. Karena untuk mendapatkan air bersih mereka harus membeli dengan harga Rp.100.000 per $1 \mathrm{~m} 3$ yang didatangkan dari daerah lain yang berjarak sekitar $20 \mathrm{~km}$ dari desa tersebut. Desa Yudha Karya Jitu merupakan salah satu desa yang ada di kecamatan Rawa Jitu Timur kabupaten Tulang Bawang propinsi Lampung. Desa tersebut merupakan salah satu daftar desa pada Kawasan Perdesaan Prioritas Nasional (KPPN). Kawasan perdesaan ini dibentuk guna mengurangi kesenjangan antara desa dan kota. Prinsipnya dengan membangun desa-desa mandiri serta membangun keterkaitan ekonomi lokal antara desa dan kota. (Humas, 2018)Untuk mengatasi masalah tersebut, maka perlu adanya alat penjernihan air menggunakan bahan yang mudah didapat (Artiyani, 2016). Bahan yang mudah didapat diantaranya adalah sekam padi, pasir,batu kerikil dan ijuk (Adi, 2014). Tujuannya agar masyarakat lebih antusias untuk membuat sendiri, karena bahan yang digunakan ada disekitar mereka. Apalagi sebagian lahan desa tersebut ditanami padi, sehingga sekam yang dihasilkan dari alat penggiling padi bisa dimanfaatkan untuk penjernihan air secara alam i. Berbeda dengan penjernihan air menggunakan teknik kimia, teknik alami lebih disukai oleh masyarakat karena biaya yang dikeluarkan untuk membuat alat lebih murah. Dari hasil penjernihan yang telah dilakukan, terlihat jelas perbedaan tingkat kejernihan air sebelum dan sesudah dilakukan.
\end{abstract}

Kata kunci: Penjernih, Air, Arang, Sekam Padi, Rawa Jitu, Tulang Bawang

\section{Pendahuluan}

Desa Yudha Karya Jitu merupakan salah satu desa yang ada di kecamatan Rawa Jitu Selatan kabupaten Tulang Bawang propinsi Lampung. Desa tersebut merupakan salah satu daftar desa yang berada di dekat Kawasan Perdesaan Prioritas Nasional (KPPN). Bagi warga desa tersebut, air bersih merupakan kebutuhan yang tak ternilai harganya. Karena untuk mendapatkan air bersih mereka harus membeli dengan harga Rp. 100.000 per $1 \mathrm{~m}^{3}$ yang didatangkan dari desa gunung tiga yang berjarak sekitar $20 \mathrm{~km}$ dari desa tersebut.

Ketentuan umum dalam Peraturan Menteri Kesehatan Nomor 416/MEN.KES/PER/IX/ tahun 1990 tentang syarat-syarat dan pengawasan kualitas air menyebutkan bahwa air bersih adalah air yang digunakan untuk keperluan sehari-hari yang kualitasnya memenuhi syarat kesehatan dan dapat diminum apabila telah dimasak. Sedangkan air minum adalah air yang kualitasnya memenuhi syarat kesehatan dan dapat langsung diminum (Alhamda, 2015).

Sudah puluhan tahun mereka tergantung pada air hujan untuk memenuhi kebutuhan seharihari, seperti mandi dan mencuci. Tetapi apabila untuk dikonsumsi mereka harus membeli dengan harga yang tidak murah. Air yang didatangkan dari daerah lain biasanya diangkut dengan mobil dan klotok (perahu) Kondisi tersebut semakin memburuk ketika musim kemarau, karena bak penampungan air hujan yang mereka bangun tidak terisi. Tanah rawa dan pasang surut air laut merupakan penyebab air bersih susah didapat di desa tersebut.

Informasi yang didapat dari salah satu warga Rawa Jitu Timur, sebenarnya sudah lama ada sumur bor, tetapi sudah lama juga sumur bor tersebut tidak mengeluarkan air. Susahnya akses jalan menuju desa tersebut mengakibatkan jarak 70 
km (simpang penawar - Rawa Jitu) ditempuh selama \pm 5 jam.

\section{Bahan dan Metode}

Adapun langkah-langkah yang akan dilakukan dalam melaksanakan Program Kemitraan Masyarakat (PKM) pembuatan alat penjernih air menggunakan arang sekam Padi adalah sebagai berikut:

Agar masyarakat desa Yudha Karya Jitu mengetahui mengenai standar kualitas air bersih adalah dengan melakukan sosialisasi, supaya menarik sosialisasi dilakukan dengan menggunakan audio visual bersama dengan tim. Ketua dibantu dengan anggota dan mahasiswa menyiapkan semua perlengkapan yang dibutuhkan dalam sosialisasi tersebut.

Adapun materi yang disampaikan antara lain standar kualitas air bersih, bahan-bahan disekitar yang mudah didapat dalam pembuatan alat penjernih air (Dewi, 2016). Dilanjutkan dengan metode tanya jawab supaya masyarakat benarbenar mengerti secara teoritis. Sosialisasi merupakan langkah awal dalam pengabdian ini. Setelah itu dilanjutkan dengan mendemonstrasikan dan pelatihan.

Bersama dengan tim dan mahasiswa masyarakat diundang untuk diberi pelatihan cara membuat alat penjernih air dari arang sekam padi. Adapun langkah-langkah dalam melakukan pelatihan yaitu:

1) Koordinasi dengan karang taruna mengenai tempat pelaksanaan dan jalannya acara

2) Mempersiapkan tempat dan segala keperluan yang dibutuhkan dalam pelaksanaan pelatihan.

3) Memperagakan bersama masyarakat mengenai pembuatan arang sekam padi.

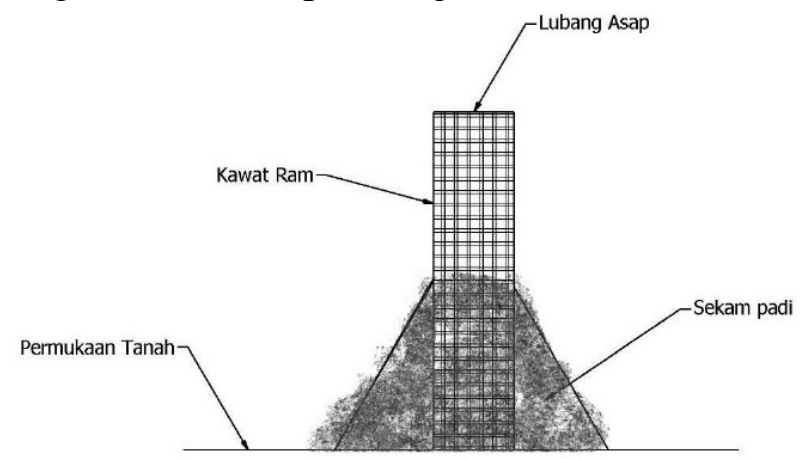

Gambar 1. Proses pembakaran sekam padi

4) Menjelaskan mengenai desain alat penjernih air serta menjelaskan alat yang sudah jadi kepada masyarakat.

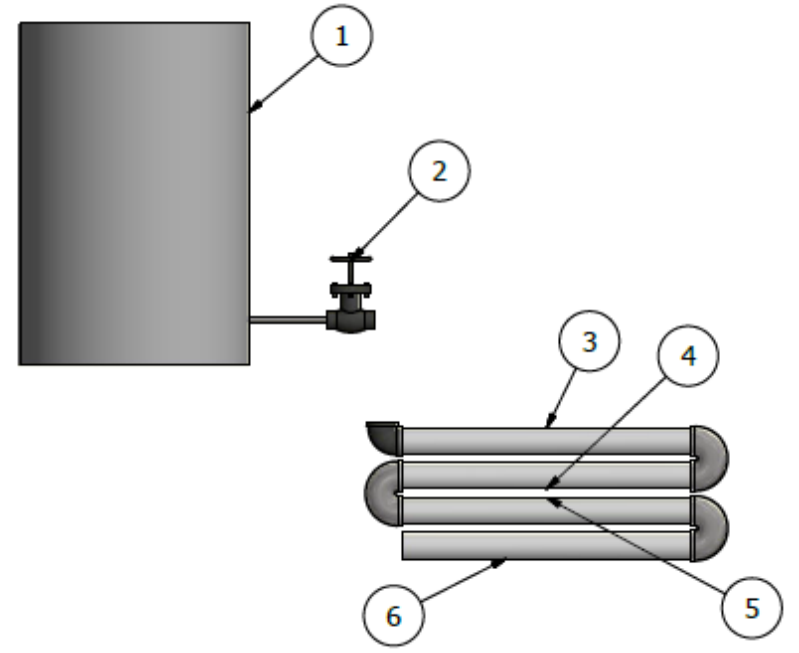

Gambar 2. Alat penjernih air

Keterangan:

1. Tangki air

2. Kran

3. Ijuk

4. Pasir

5. Arang sekam padi

6. Batu Zeolit

Alat yang digunakan dalam pembuatan alat penjernih air ini adalah sebagai berikut:

1. Gergaji Potong

2. Tang Potong

3. Meteran

Bahan yang digunakan dalam pembuatan alat penjernih air ini adalah sebagai berikut:

1. Tandon air

2. Pipa PVC

3. Sambungan Pipa

4. Lem Pipa

5. Arang Sekam

6. Kayu bakar

7. Kawat Ram

8. Kerikil (Zeolite)

9. Ijuk

\section{Hasil dan Pembahasan}

Ilmu pengetahuan yang dapat diperloleh oleh masyarakat dengan adanya kegiatan pengabdian ini adalah pengetahuan mengenai standar kualitas air bersih serta bahaya-bahaya mengkonsumsi air kurang bersih terhadap kesehatan jasmani semakin meningkat. Dengan adanya teknologi alat penjernih menggunakan arang sekam padi ini, masyarakat bisa membuat sendiri alat tersebut untuk di aplikasikan pada setiap rumah-rumah. Karena bahan-bahan yang diperlukan mudah di dapat, 
tidak menggunakan proses kimia yang memerlukan biaya mahal (Windarto, 1996).

Cara kerja alat penjernih air dari arang sekam padi ini adalah menjernihkan air tanah akibat terjadinya pasang surut air laut di kampung Yudha Karya Jitu (Yulianti, 2015). Mula-mula air tanah yang diambil diendapkan di drum selama 3-6 hari, kemudian dialirkan pada drum lain yang telah diisi dengan lapisan ijuk, arang sekam padi dan batu Zeolite (Rahayu, 2015). Air yang dituangkan akan disaring secara berlapis, sehingga pada saat keluar dari kran sudah bersih. Dengan adanya alat tersebut diharapkan masyarakat kampung Yudha Karya Jitu menjadi terbantu, mengurangi pengeluaran untuk membeli air bersih yang didatangkan dari daerah lain.

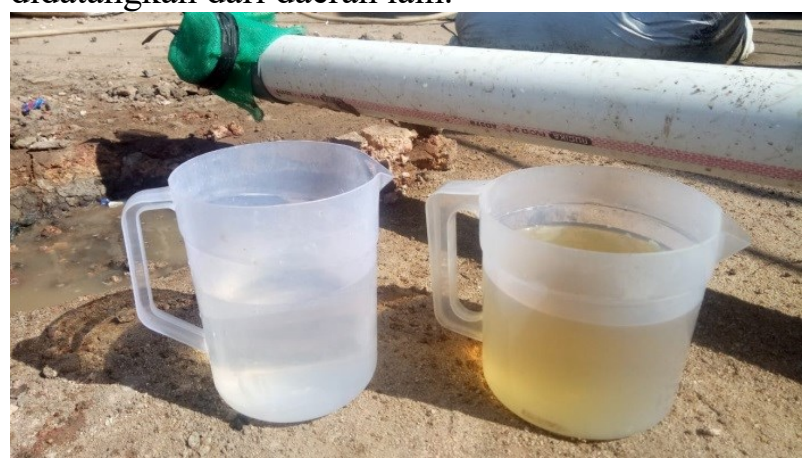

Gambar 3. Setelah dijernihkan (kiri), Sebelum dijernihkan (kanan)

\section{Kesimpulan}

Setelah kegiatan pengabdian ini, ada beberapa kesimpulan yang telah didapat:

1. Pengetahuan masyarakat menjadi bertambah tentang penjernihan air dengan bahan yang mudah didapat.

2. Keterampilan masyarakat menjadi meningkat dengan adanya pelatihan pembuatan alat penjernih air menggunakan arang sekam padi.

3. mengurangi pengeluaran untuk membeli air bersih yang didatangkan dari daerah lain.

Saran untuk kegiatan selanjutnya dalam pengabdian ini adalah meneliti hubungan antara volume bahan yang digunakan terhadap volume air jernih yang dihasilkan. Sehingga dapat dihitung berapa lama alat tersebut harus dibersihkan atau diganti bahannya.

\section{Ucapan Terima Kasih:}

Kami ucapkan terima kasih kepada Direktorat Riset dan Pengabdian Masyarakat Direktorat Jenderal Riset dan Pengembangan Kementerian Riset, Teknologi, dan Pendidikan Tinggi yang telah mendanai kegiatan Program Kemitraan Masyarakat (PKM) ini. Kami ucapkan terima kasih juga kepada pihak-pihak yang telah mendukukng dan membantu pelaksanaan kegiatan ini antara lain UM Metro khususnya LPPM, Karang taruna kampung Yudha Karya Jitu, dan para Mahasiswa.

\section{Daftar Pustaka}

Humas. (2018, April 09). Tersedia, Lokasi 30-40 KPPN. Retrieved from Situs Resmi Kementerian Koordinator Bidang Pembangunan Manusia dan Kebudayaan: https://www.kemenkopmk.go.id/artikel/tersedialokasi-30-40-kppn

Artiyani, A., \& Firmansyah, N. H. (2016). Kemampuan Filtrasi Upflow Pengolahan Filtrasi Up Flow dengan Media Pasir Zeolit dan Arang Aktif dalam Menurunkan Kadar Fosfat dan Deterjen Air Limbah Domestik. INDUSTRI INOVATIF JURNAL TEKNIK INDUSTRI, 6(1).

Adi, W. (2014). Efektifitas Filter Bahan Alami Dalam Perbaikan Kualitas Air Masyarakat Nelayan Wilayah Pesisir Kabupaten Bangka. AKUATIK, 34-39

Alhamda, S. (2015). Buku Ajar Ilmu Kesehatan Masyarakat (IKM). Yogyakarta: Deepublish.

Dewi, Y. S., \& Buchori, Y. (2016). Penurunan COD, TSS Pada Penyaringan Air Limbah Tahu Menggunakan Media Kombinasi Pasir Kuarsa, Karbon Aktif, Sekam Padi Dan Zeolit.

Windarto. (1996). Teknologi Tepat Guna Membuat Alat Penjernih Air. Yogyakarta: Kanisius.

Yulianti, A. (2015). Prototype Alat Pengolahan Air Laut Menjadi Air Minum (Pengaruh Variasi Packing Filter Terhadap Kualitas Air Dengan Analisa Do, Salinitas, Dan Konduktivitas) (Doctoral dissertation, Politeknik Negeri Sriwijaya).

Rahayu, A., Masturi, M., \& Yulianti, I. (2015). Pengaruh Perubahan Massa Zeolit Terhadap Kadar Ph Limbah Pabrik Gula Melalui Media Filtrasi. Jurnal Fisika, 5(2).. 